\title{
Socialism and Domesticity: The "Familistère" at Guise
}

\section{Theresa M. McBride}

\author{
College of the Holy Cross
}

In 1968 while a student and workers movement was making political lif. difficult for President Charles De Gaulle of France. another revolutionary experi ment was quietly coming to an end. One of the few successful utopian livin:? communities was dissolved. The "familistere" of Guise created by socialist Jear? Baptiste Godin in 1857, ceased to be collectively owned in that year atter 110 years of existence.

The community at Guise, which is about at wo-hour drive from Paris toward the northeast, was founded by ironworker Jean-Baptiste Godin in 1846. The foundry made a fortune for Godin from the production of cast-iron cooking pots and by 1848 Godin was sufficiently well-known in the areat to be elected to the constituent assembly. With the failure of the revolution of 1848 . Godin resolved to find his own route to social reform and committed one-third of his fortune to the building of a "familistere" based on the ideas of socialist Charles Fourier.

The "familistere" is a remarkable community. It consists of three rectangular apartment blocks which in 1857 housed 300 workers and their families. At its height, the community comprised 900 families: though only about one-fourth of the foundry's work force was ever housed there. In 1968, the connection of the "familistere" to the foundry was severed by the new German owners of the Godin works, and the apartments are now owned by their individual occupants.

The village is the architectural expression of the utopian ideals which inspired it. ${ }^{1}$ Each of the three apartment blocks is organized around a central court yard, paved with cement and covered by a glass roof. Acting as his own architect. Godin tried to assure the inhabitants of all the domestic comforts: there is a system of air circulation and ventilation, piped-in water was available on each floor, and garbage and sewage disposal systems were very modern for the 18.50 s. The rooms of the apartments have high ceilings (about $8^{\prime}$ ) and light penetrates through windows which open onto the sky-lit central court. Many appects of the design! were revolutionary: clothes-washing facilities used the hot water run-off from the foundry; there was a mixed-sex school for children under fourteen (unique in a country of single-sex education) and a day nursery. Godin encouraged the use of 
the swimming pool and athletic field and was a great believer in the efficacy of exercise and personal hygiene. He linked the moral and social reform of workingclass life to hygiene in a way that was much more common later in the nineteenth century, and he insisted that light and space were primary "rights" of human beings.

The community at Guise demonstrates some of both the good and bad characteristics of utopian designs. Cafés which served non-alcoholic beverages were included among the other shops in the commercial section of the project, but Godin prohibited the opening of bars for fear of the dissipation of workers energries in alcohol. The founder of the community and his wife lie buried in the lovely park adjoining the "familistère" under a massive monument which celebrates both the dignity of work and of motherhood. Godin's intention to reduce individual housework by centralizing cleaning services and cooking were only partially successful; French workers resisted the idea of eliminating private kitchens in exchange for collective dining and cooking areas. Emile Zola, himself a socialist, criticized the experiment as a "glass house" in which there was "no privacy . . no freedom." The discipline and controlled atmosphere made him regret that comfort seemed to take precedence over individuality. Like other socialist experiments, the "familistere" was no mere living arrangement, but a total experience in reforming the human spirit."

Like his foundry, Godin"s "palace of the people" was a great success. In 1871, the mayor of Guise was among the few socialists elected to the National Assembly. His book, Solutions sociales, which helped to popularize the communitarian experiment at Guise was also published in that year. Solutions sociales traces some of Godin's early life and the formulation of his political ideas. Recently republished in France, Solutions sociales includes the original designs for the village by its amateur architect." Both the "familistère" and Solutions sociales are the acheivements of a remarkable mind.

The "familistere" at Guise retains its basic plan and is well worth a detour if one happens to be travelling in France or Belgium. The community's library serves as a museum of its history and includes a scale-model of the project, memorabilia of the founder, and numerous photographs and books which document the experiment's long lite."

\section{NOTES}

1. My own interen in the "familistere" was inspired by a project on the connections between social reformism and architectural modernism.

2. Cf. Roger Guerrand, Les Origines du logement social en France (Paris, 1967),

3. Jean-Baptiste Codin. Solutionss sociales (Quimper: Editions la Digitale, 1980. 65 francs. Originall: publithed in Paris in 1871).

4. Godin's widow collected documentation on her husband's work which was published in $19(04$ in thee volunes: Marie Moret, Decuments pour une Biographie complète de J.B.A. Godin, rasiombles por saterie 